\title{
PROPOSED BUSINESS STRATEGY IMPROVEMENT THROUGH SERVICE QUALITY GAP MODEL TO INCREASE MEMBERSHIP COVERAGE OF BPJS KETENAGAKERJAAN
}

\author{
Harimukti Wandebori \\ School of Bussiness and Management, Institut Teknologi Bandung \\ E-mail: harimukti99@yahoo.com
}

\begin{abstract}
BPJS Ketenagakerjaan is a public legal entity based on Law No. 24 of 2011 which is given a mandate by the Government to provide social security protection for all workers in Indonesia. This study aims to find out and improve the BPJS Ketenagakerjaan strategy based on service quality issues. The methodology used in this study using quantitative methods by measuring the service quality gap model to determine the expectations of participants and the ability of the organization to provide services. Secondary data analysis was from company-internal data and literature studies to assess various analysis using methods; such as environmental analysis, SWOT, and TOWS Matrix. The strategy to be implemented is the differentiation strategy. BPJS Ketenagakerjaan needs to create three core competencies, namely reliability, responsiveness, and innovation, to create a superior service quality and added value for customers.
\end{abstract}

Keywords: social security, service quality Gap, business strategy

\begin{abstract}
ABSTRAK
BPJS Ketenagakerjaan adalah badan hukum publik berdasarkan UU No. 24 tahun 2011 yang diberi mandat oleh Pemerintah untuk memberikan perlindungan jaminan sosial bagi semua pekerja di Indonesia. Penelitian ini bertujuan untuk mengetahui dan meningkatkan strategi BPJS Ketenagakerjaan berdasarkan masalah kualitas layanan. Metodologi yang digunakan dalam penelitian ini menggunakan metode kuantitatif dengan mengukur model kesenjangan kualitas layanan untuk menentukan harapan peserta dan kemampuan organisasi untuk menyediakan layanan. Analisis data sekunder berasal dari data internal perusahaan dan studi literatur untuk menilai berbagai analisis menggunakan metode; seperti analisis lingkungan, SWOT, dan TOWS Matrix. Strategi yang akan diterapkan adalah strategi diferensiasi. BPJS Ketenagakerjaan perlu menciptakan tiga kompetensi inti, yaitu keandalan, daya tanggap, dan inovasi, untuk menciptakan kualitas layanan yang unggul dan nilai tambah bagi pelanggan.
\end{abstract}

Kata kunci: jaminan sosial, kesenjangan kualitas layanan, strategi bisnis 


\section{INTRODUCTION}

Social security is critical to every nation in the world, especially in developing countries, to ensure all citizens to fulfill the basic needs of a decent life, including Indonesia. As stipulated in Constitution 1945 Article 34 paragraph (2), the State develops a social security system for all people and empowers powerless and lower-income people with human dignity. In light of this obligation, the Government issued Law No. 40/2004 as the legal framework for establishing a National Social Security System (SJSN), and Law No. 24/2011 about the establishment of two Social Security Providers. The providers consist of BPJS Kesehatan, a transformation of PT. Askes (Persero), and BPJS Ketenagakerjaan, a transformation of PT. Jamsostek (Persero).

The Law No. 40/2004 and Law No. 24/201 1 enables the Government of Indonesia to make a significant improvement in expanding the social protection scheme for both formal and informal workers. BPJS Ketenagakerjaan is established to run a security and welfare program for all workers and their family through four social security programs (covering provident funds, work accident benefits, death benefits, and pension funds). The business model of BPJS Ketenagakerjaan is a non-profit public organization which recognizes contribution fee as the primary source of income for the sustainability of the organization in carrying out social security programs.

In general, the measurement of success of social security is from the extent of the social security protection coverage in public. The law stated that social security programs are for all people. Besides that, according to Kientzler (2001), it was noted that some social security providers in the world measure their success with the quality of their services and efficiency. The social security agencies in various countries are urged more to provide higher quality service and more efficient work system.

For approximately four decades, Indonesia has run several social security programs, but only covers a small percentage of the population. In 2017, the coverage share of the active participant only reached $28 \%$. It shows that a small number of workers only feels social security as essential protection. Besides that, BPJS Ketenagakerjaan, as a Public service institution in Indonesia, should focus on the improvement of quality of service. It is due to the increasing public demand for service quality.

Excellent service quality will have an impact on customer loyalty expected by customers who are loyal to a product or service and make repeated purchases and refer to others (Parasuraman \& Grewal, 2000). Therefore, the quality of services provided by BPJS Ketenagakerjaan will have an impact on increasing participation if appropriately managed. 


\section{Harimukti Wandebori}

Refers to the business issues, BPJS Ketenagakerjaan requires an appropriate strategy based on analysis of service quality gap, resources, and capability. It is necessary to support increased membership coverage of BPJS Ketenagakerjaan.

\section{METHODS}

The method in this study begins with making a conceptual framework for formulating business strategies based on known business issues. After determining the conceptual framework, the author analyzes current business situation, beginning with the internal analysis. It consists of resource analysis to highlight the internal capabilities and value chain analysis to understand the part of its operations (value chain activities) that create value. The external analysis consists of PEST analysis (political, economic, socio-cultural and technology) to understand the market trends, risk, position, potential, and direction of the business. It uses Porter's five forces analysis, and competitor analysis by identifying key competitors, assessing objectives, strategies, and strengths and weaknesses to unravel the threats. The next step, author constructs variables using quantitative methods of measuring service quality gap model based on Parasuraman. It determines the expectations of participants and the ability of the organization to provide services. Finally, use SWOT Analysis to describe the strengths, weaknesses, opportunities, and threats of BPJS Ketenagakerjaan.

\section{Conceptual Framework}

The author tries to discuss the conceptual framework as a guide to create a strategy which was suitable for its business. Conceptual framework is about how the relation of theories relating to research variables that want to be studied. The figure below is a conceptual framework of this research.

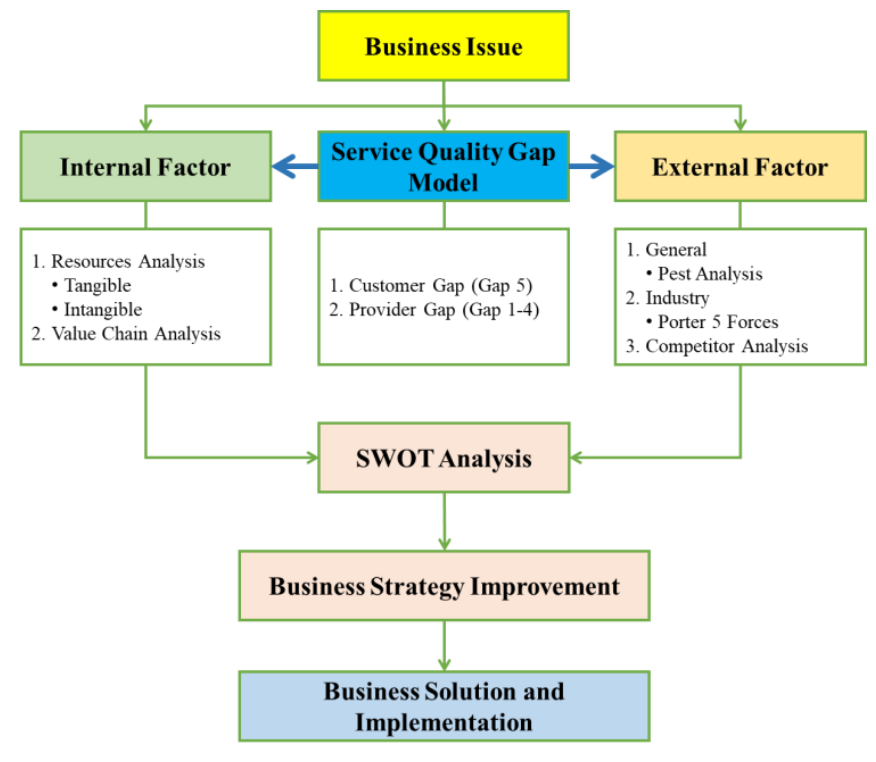

Figure 1.

Conceptual Framework 
The first step is to analyze aspects of the selected object, both internal and external. External analysis use PEST, Porter's five forces, and Competitor analysis. Internal Analysis uses resources and value chain analysis. After that, this study uses the service quality gap model to find out the extent of the services provided by BPJS Ketenagakerjaan. The result of the analysis will help to determine the feasible strategies.

\section{Method of Data Collection}

This research is conducted by quantitative and qualitative approaches to identify the correct strategy to solve the business issue that is faced by BPJS Ketenagakerjaan with the following methods:

\section{Primary data collection}

Primary data collection is needed to measure the service quality gap obtained through the questionnaire. Service Quality Analysis (SERVQUAL) is a descriptive method to describe the level of customer satisfaction. Figure 2 shows the conceptual model of service quality. It aims to evaluate dimensions along with the relationship between provider and customers. It conveys a clear message to managers wishing to improve their quality of service.

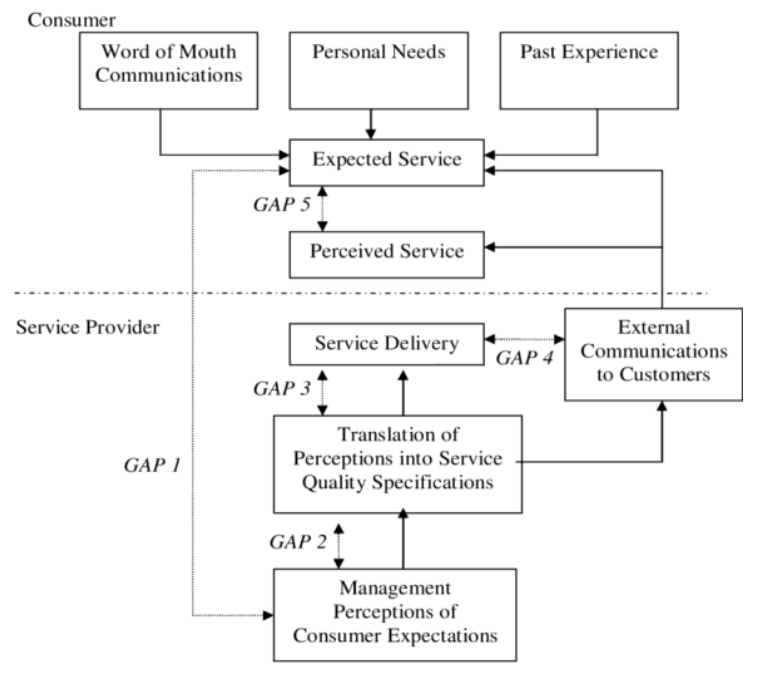

Figure 2.

Conceptual Model of Service Quality

Source: an adaptation from Parasuraman and Grewal (2000).

This questionnaire consists of three types of respondents, namely customer, manager, and staff. The author distributes sample size of surveys with the following amounts: 
Table 1.

Questionnaire Respondents

\begin{tabular}{clc}
\hline No & \multicolumn{1}{c}{ Types of Respondents } & Number of Samples \\
\hline 1 & Participant of BPJS Ketenagakerjaan & 200 \\
2 & Manager & 100 \\
3 & Staff & 500 \\
\hline
\end{tabular}

According to Taherdoost (2016), number of sample with minimum of 100 respondents can represent the population, particularly, when there is a large of population number. In the object of investigation, the number of employees at BPJS Ketenagakerjaan of 4,446 can be considere as large quantity.

\section{Literature studies}

The literature study is used to collect data or sources related to the topics in this study. The study literature is to learn about the business theories used in this article, such as for analyzing internal and external environment, a theory of corporate strategy, and service quality gap. The literature study, then all combined and adapted to the case of BPJS Ketenagakerjaan.

\section{Analysis}

In this study, the strategic management process begins with an internal factor and external factor analysis. Besides that, the author explores further investigation through the service quality model. All of these analyses aim to find out the business situation and know the strengths, weakness, opportunities, and threats of BPJS Ketenagakerjaan.

\section{Internal Factor Analysis}

The framework used to analyze the internal analysis of BPJS Ketenagakerjaan are resources and value chain activity. Having analyzed the internal, BPJS Ketenagakerjaan will recognize its strength and weakness and determines what it can do as institutional resources.

\section{Resources Analysis}

\section{Financial Resource}

The fund managed by BPJS Ketenagakerjaan up to the end of 2017 reached Rp.317 billion. During the last three years, BPJS Ketenagakerjaan had an excellent financial performance, as shown by the increasing number of assets. Solvency Ratio of JHT program in 2016 was 101.48\%, up from 2015 at 1.24\% (BPJS Ketenagakerjaan, 2017). It was due to the excellent performance of investments that have an impact on the increase in investment funds. The liquidity ratio for the JKK and JKM programs in 2016 has increased too, that was due to high contribution revenues and low benefit payments that increased net asset balance. 


\section{Organizational Resources}

In the last two years, BPJS has made changes to the organizational structure. Organizational Structure of BPJS Ketenagakerjaan is a functional and matrix form. It accommodates relationship among head office, regional offices, and branch offices and has a working method set in the Board of Directors Regulation.

\section{Physical Resources}

The operational area of BPJS Ketenagakerjaan covers the whole territory of the Republic of Indonesia and does not have representation abroad. Until the end of 2016, there are 336 BPJS Ketenagakerjaan offices includes one unit head office, 11 regional offices, 121 branches, and 203 sub-branches. The number of branch office channels is still low compared to the number of districts/cities spread across Indonesia.

\section{Technological Resources}

Currently, BPJS Ketenagakerjaan continues to increase the capacity of technology as operational support in the design of information systems architecture. With integrated information, the system can provide an option for all stakeholders in transactions with BPJS Ketenagakerjaan and expected to be the strength of BPJS Ketenagakerjaan in achieving operational excellence strategy and improve service quality as one of the competitive advantages.

\section{Human Resources}

The number of employees of BPJS Ketenagakerjaan until the end of 2017 there are 5,556 people. Their placements are spread over the head office, regional offices, branch offices, and sub-branch offices across Indonesia. The majority of BPJS Ketenagakerjaan employees based on education level are graduates of Strata- 1 that is equal to $73.52 \%$ and Diploma (D3) that is equal to $16.39 \%$. Whereas if viewed by age group, the majority generation of BPJS Ketenagakerjaan employees is Generation $Y(21-30)$ that is equal to $52.25 \%$ or as many as 3,170 employees. BPJS Ketenagakerjaan recognizes that the dominant Gen Y composition needs to be well managed.

\section{Innovation Resources}

In terms of management of Innovation Resources, BPJS Ketenagakerjaan has made the rules of directors on guidelines for the management of innovation BPJS Ketenagakerjaan as part of continuous improvement known as Insanova BPJS Ketenagakerjaan. 


\section{Harimukti Wandebori}

\section{Reputation Resources}

\section{Brand}

Currently, most people are not familiar with BPJS Ketenagakerjaan. Besides that, there is also a negative perception in the brand "BPJS." Furthermore, people do not understand the difference between BPJS Ketenagakerjaan and BPJS Kesehatan. Therefore, people often perceive that these two institutions are the same Institution. Even up to the last Axia survey in 2017, 57\% of respondents expect that BPJS Ketenagakerjaan and BPJS Kesehatan are the same institutions.

\section{Customer Satisfaction}

The level of customer satisfaction decreased slightly from 2015 to 2016 , from $90.2 \%$ to $88.2 \%$.

\section{Value Chain Analysis}

Value chain analysis consists of two activities, which are primary activities and support activities. In carrying out business activities, BPJS Ketenagakerjaan uses the value chain analysis as follows:

\section{Primary Activities}

- Membership activities - Have a goal to expand the scope of participation, manage participants, and build relationships with stakeholders.

- Supervision and Inspection Activities - Manage supervision and inspection activities of participants/prospective participants, law enforcement, and partnership activities between BPJS Ketenagakerjaan with government / non-government institutions.

- Investment Activities - Manage BPJS Ketenagakerjaan assets and social security assets to have added value for participants.

- Service Activities - Manage policies and strategies for managing program benefits and operational services to create operational excellence, excellent customer experience, and improve service satisfaction for participants.

\section{Support Activities}

- Financial Activities - Management of operational budgets and social security funds effectively, efficiently and transparently.

- Human Capital and General Activities - Coordinate and control the activities of public and human resources and provide optimal support to the operational activities.

- Information Technology Activities - Management and development of information technology to support BPJS Ketenagakerjaan goals.

- Governance Activities - Manage all policies in the organization so that the planned organizational goals are achievable. 
Based on value chain analysis, the author concludes that there are several problems or weaknesses in business activities that need improvement described, as shown in Table 2.

\section{Table 2.}

Review of Existing Value Chain Analysis

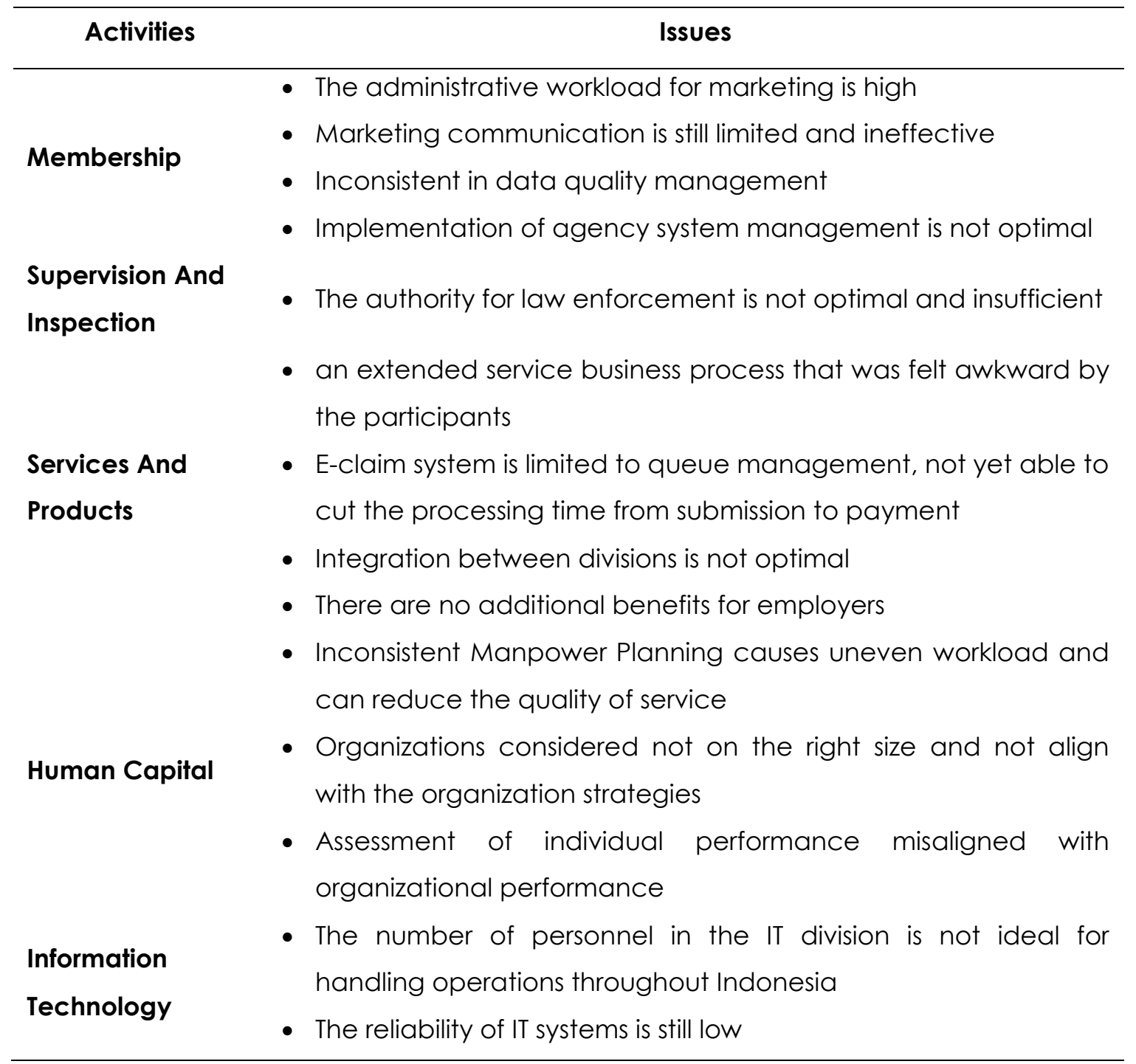

\section{External Factor Analysis}

External factor analysis is essential for BPJS Ketenagakerjaan to understand the environment and the business situation that happens out there. Therefore, BPJS Ketenagakerjaan pays attention and responds to changes in the environment to ensure sustainability.

\section{General}

The general environment consists of dimensions in the broader society that influence BPJS Ketenagakerjaan, which is uncontrollable by the organization, including Political, Economic, Socio-cultural, and Technological. 


\section{Harimukti Wandebori}

\section{Political}

Change into public legal entity status causes political and legal factors to be the main factor of BPJS Ketenagakerjaan in running its operations. BPJS Ketenagakerjaan is directly responsible to the president. Therefore, the president's political decision can change of social security policy in Indonesia and have an impact on the business continuity of BPJS Ketenagakerjaan. Current policies have more harmful and detrimental effects on BPJS Ketenagakerjaan, including Government regulations that do not support operations in the implementation of Employment Social Security.

\section{Economic}

In terms of economic growth, based on data from the World Bank (2018), the Indonesian economy continued to increase in the first quarter of 2018, driven by robust investment. Private consumption was expected to increase slightly, and investment growth was predicted to remain high, consumption grew $4.95 \%$, and investment rose $7.9 \%$. Unstable economic growth may affect the value of investments made by BPJS Ketenagakerjaan. However, growth in private consumption was not able toincrease the growth in the number of participants of BPJS Ketenagaekrjaan.

\section{Social}

Indonesia is entering a demographic bonus, which the population with a productive age (15-64 years) is more than the people with an unproductive period ( $>65$ years). This condition beneficial for Institution because it means that it is a good signal for BPJS Ketenagakerjaan where the potential of workers and informal workers is increasing.

However, on the other side, The Financial Services Authority (OJK)(2017) noted that Indonesia's insurance utilization rate was only 11.81 percent in 2016. The potential of the insurance market in Indonesia is still quite significant, many people are capable, but the public is not aware of the importance of insurance. BPJS Ketenagakerjaan should be able to respond to this condition, by continuing to educate to change society mindset related insurance or social insurance employment.

\section{Technological}

The number of Internet users in Indonesia in 2016 is 132.7 million users or about $51.5 \%$ of the total population of Indonesia (APJII, 2016). Most Internet users are on Java Island, with a total of $86,339,350$ users that is equal to $65 \%$ of the overall use of the people (APJII, 2016). Currently, most people already have access to the Internet quickly via mobile phones. In addition to mobile phones, Internet technology will continue to evolve. Ease of internet access at various locations as well as efforts to encourage the dissemination of the Internet 
will make more and more people connect to the Internet. Future technological trends will have an impact on the employment sector, both challenges, and opportunities. The problems that arise from the technological trend are: (a) Uneven and low understanding of IT or digital for the people in the regions, (b) High expectations from the society towards the service quality, especially public services, (c) The automation process replaced the loss of several jobs. And the opportunities that arise from the future technological trends are: (a) Speed up and simplify work, (b) The emergence of new jobs related to digital technology.

\section{Industry Environment}

The industry environment has a more direct effect on the firm's strategic competitiveness and ability to earn above-average returns. Porter's Five Forces Analysis is an essential tool for analyzing the competitive nature of BPJS Ketenagakerjaan to make a strategic decision to increase membership and contribution revenue.

\section{The threat of New Entrants}

Implementation of social security is mandated by law so that it will be difficult that a newcomer can enter to social security industries to compete with BPJS Ketenagakerjaan. From this analysis, the Threat of New Entrants for BPJS Ketenagakerjaan is low.

\section{Bargaining Power of Suppliers}

There are three BPJS Ketenagakerjaan Suppliers, namely, Data suppliers, Hospital, and Banking. Social security industries are the primary customer of the supplier, so the tendency of suppliers to impose their strength on the industry is low.

\section{Bargaining Power of Buyers}

Workers and companies as buyers have no choice in participating in social security program because this program is compulsory according to the law. From this analysis, the bargaining power of buyers for BPJS Ketenagakerjaan is low.

\section{The Threat of Substitute Products}

Insurance companies are not competitors of BPJS Ketenagakerjaan, because they are not part of government programs. Besides that, companies do not require the employees to register as participants. However, Insurance companies can create and offer similar products with promotional benefits. The situation can lead to the switching of participants JHT, JKM, JKK, and JP and be a substitution product for BPJS Ketenagakerjaan. From this analysis, the Threat of Substitute Products for BPJS Ketenagakerjaan is medium. 


\section{Harimukti Wandebori}

\section{The intensity of Rivalry Among Competitors}

BPJS Ketenagakerjaan is superior because it is an agency formed by the Government to organize Labor Social Security for all workers in Indonesia. On the other hand, commercial insurance with social security is not a rival but is considered to be a complementary product. From this analysis, the intensity of rivalry among competitors for BPJS Ketenagakerjaan is low.

\section{Competitor Analysis}

BPJS Ketenagakerjaan is the only provider of social insurance that is officially addressed by the law to provide employment social security to all labor markets. However, BPJS Ketenagakerjaan needs to be aware of the existence of companies that offer similar programs which can be an option for workers to convert JHT, JKM, and JKK. The consequences of this mandatory program can increase workers' demands and expectations on the quality of product and service by comparing the quality of other institutions. In this competitor's analysis, the author chose Prudential Life Assurance as a competitor because Prudential until 2017 is still the market leader (Table 3).

\section{Service Quality Analysis \\ Validity and Reliability Test}

In this research, the author used SPSS Statistics 17.0 to do the validity and reliability test. Validity test uses corrected item-total correlation by comparing the value of $r$ count with $r$ table. The number of samples tested is 50 due to the maximum number of questions each dimension is 5 . Based on the calculation of the validity test with a significance level of $5 \%$, the results of $r$ count is 0.279 , so if $r$ count is greater than $r$ table, then the question is "acceptable." The reliability test uses Cronbach's Alpha. The reliability coefficient (Cronbach's Alpha) of 0.70 or higher is "acceptable." The entire test shows that all question items are valid and reliable.

\section{Analysis Results}

Based on the previous analysis on the questionnaire, from the five dimensions measured, BPJS Ketenagakerjaan still has gaps in service quality. The table shows that there are prioritized service quality gaps (Table 4).

\section{SWOT Analysis}

From the results of external, internal, and service quality gap analysis, the author summarizes the situation of BPJS Ketenagakerjaan through SWOT analysis. The following is a SWOT analysis of BPJS Ketenagakerjaan (Table 5). 
Table 3.

Competitor Analysis

\begin{tabular}{|c|c|c|}
\hline Item & BPJS Ketenagakerjaan & Prudential Life Assurance \\
\hline Objective & $\begin{array}{l}\text { - Protect and prosper all workers } \\
\text { and their families } \\
\text { - Increasing productivity and } \\
\text { competitiveness of workers } \\
\text { - Support the development and } \\
\text { independence of the national } \\
\text { economy }\end{array}$ & $\begin{array}{l}\text { - Become the best Retail Financial Services } \\
\text { Company in Indonesia. } \\
\text { - It is providing insurance services that offer } \\
\text { benefits to the community. } \\
\text { - Providing quality services and products as } \\
\text { well as highly committed professional } \\
\text { marketing personnel } \\
\text { - Achieve equitable benefits for all } \\
\text { stakeholders and shareholders. }\end{array}$ \\
\hline $\begin{array}{l}\text { Current } \\
\text { Strategy }\end{array}$ & $\begin{array}{l}\text { id Education } \\
\text { cellence } \\
\text { int }\end{array}$ & $\begin{array}{l}\text { - Differentiation products to meet the needs } \\
\text { of long-term financial protection and meet } \\
\text { the needs of customers in all age groups. } \\
\text { - Digital service improvement } \\
\text { - CSR implementation in terms of financial } \\
\text { literacy }\end{array}$ \\
\hline Capabilities & $\begin{array}{l}\text { - Large Managed Fund } \\
\text { - Have a physical and digital } \\
\text { service channel (Omni } \\
\text { Channel) } \\
\text { - Strategic Partnership } \\
\text { - Developing agency system } \\
\text { - Have competent human } \\
\text { - Hapital } \\
\text { - Has an integrated IT system }\end{array}$ & $\begin{array}{l}\text { - Positive asset growth } \\
\text { - Top Brand Index } \\
\text { - Reliable applications and information } \\
\text { systems } \\
\text { - More than } 290.000 \text { licensed agents who } \\
\text { sales directly to the customers } \\
\text { - HR training and motivation process } \\
\text { regularly. } \\
\text { - Strategic Partnership (bank, Prudential } \\
\text { Medical Network) }\end{array}$ \\
\hline Prod & $\begin{array}{l}\text { - Four main products that have } \\
\text { been regulated by law are } \\
\text { Work Accident Benefit, Death } \\
\text { Benefit, Provident Fund Benefit, } \\
\text { Pension Benefit } \\
\text { - Have additional product } \\
\text { benefits such as the benefits of } \\
\text { homeownership }\end{array}$ & $\begin{array}{l}\text { - Prudential tries to offer products according } \\
\text { to customers' needs and goals. Prudential } \\
\text { has a variety of protections, such as } \\
\text { inpatient protection, critical condition } \\
\text { protection, life insurance, and products } \\
\text { with investment elements. }\end{array}$ \\
\hline Place & $\begin{array}{l}\text { - Branch offices are } 121 \text { units, } \\
\text { Sub-Branch Offices Total } 203 \\
\text { units throughout Indonesia } \\
\text { - Having a service channel in } \\
\text { collaboration with banks }\end{array}$ & $\begin{array}{l}\text { - Prudential Indonesia has a marketing office } \\
\text { in Medan, Surabaya, Bandung, Denpasar, } \\
\text { Batam and Semarang and } 408 \\
\text { Independent Marketing Offices (KPM) } \\
\text { throughout Indonesia }\end{array}$ \\
\hline
\end{tabular}

\section{Result and Discussion}

After trying to analyze the conditions and current situation faced by BPJS Ketenagakerjaan, there are some conclusions that the author can convey that will be explained further in this section.

\section{Alternative of Business Solution}

From the steps previously mentioned, a suitable business strategy is a solution that must be prioritized and considered. The business solution is from the internal analysis, external analysis, and Service Quality Gap. Based on the analysis results, BPJS Ketenagakerjaan must improve its weaknesses in terms of reliability, responsiveness, and marketing communication. These business solutions are following strategy systematically. 
Table 4.

Conclusion of Service Quality Gap in BPJS Ketenagakerjaan

\begin{tabular}{|c|c|c|c|}
\hline \multicolumn{2}{|c|}{ GAP } & \multirow[t]{2}{*}{ Priority to Improve } & \multirow{2}{*}{$\begin{array}{l}\text { The resource to be Developed } \\
\text { - Improve IT Infrastructure and capacity }\end{array}$} \\
\hline \multirow{5}{*}{ Customer } & & & \\
\hline & & Reliability & - Expand Digital and physic channel \\
\hline & Gap 5 & & - Business process Simplification \\
\hline & & & - Fulfillment of Human Resources \\
\hline & & respotisivetiess & - Enhance personnel competencies \\
\hline \multirow{9}{*}{$\begin{array}{l}\text { Provider } \\
\text { Gap }\end{array}$} & & Marketing Research & \\
\hline & sup 1 & Orientation & E Hirke \\
\hline & & Management & \\
\hline & Gap 2 & Commitment to Service & \\
\hline & & Quality & quniाly \\
\hline & & Perceived control & $\begin{array}{l}\text { - Improve personnel workload based on } \\
\text { function }\end{array}$ \\
\hline & Gap 3 & $\begin{array}{l}\text { Supervisory control } \\
\text { systems }\end{array}$ & $\begin{array}{l}\text { - Improve KPI to more focus on service } \\
\text { quality }\end{array}$ \\
\hline & & Role conflict & - improve the manpower planning system \\
\hline & Gap 4 & $\begin{array}{l}\text { Propensity to } \\
\text { overpromise }\end{array}$ & - integration among divisions \\
\hline
\end{tabular}

\section{Business-Level Strategy}

Based on these characteristics and to be able to sustain as an institution to implement employment social security programs, the differentiation strategy might be suitable for BPJS Ketenagakerjaan. Some of the reasons why differentiation is appropriate to be applied by BPJS Ketenagakerjaan are:

- Products and prices have been set by the Government so that differentiated products create unique values that satisfy customers.

- Improvement of customer's expectations for BPJS Ketenagakerjaan services is from the result of reliability and responsiveness dimensions. Therefore, continuous innovation in business processes and IT Development are necessary to improve the quality of BPJS Employment services. 
Table 5.

SWOT Analysis

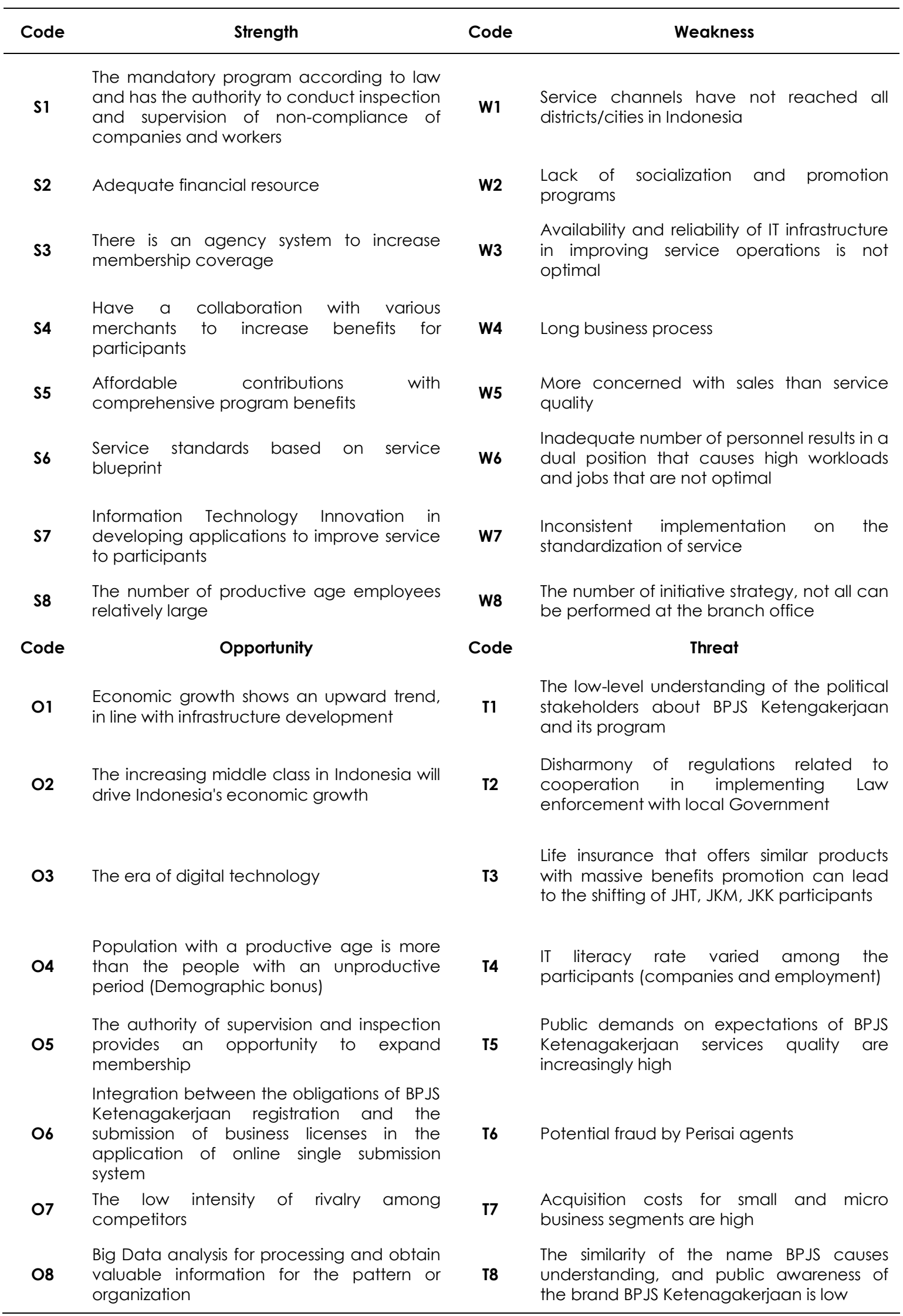




\section{Harimukti Wandebori}

\section{Proposed Core Competencies}

Based on the summary of internal, external, and service quality gap analysis, the author tries to offer three core competencies based on the previous analysis as follows:

Table 6.

BPJS Ketenagakerjaan Core Competencies

\begin{tabular}{lll}
\hline No Core Competencies & \multicolumn{1}{c}{ Resource Development } \\
\hline $1 \quad$ Reliability & - Information technology capability \\
& - Financial capacity \\
& - Collaborative business \\
& - Data management \\
& - Align the organization \\
& - Integrated business process \\
& - Improve human resource quantity and quality \\
& - Innovation culture \\
& & - Product development
\end{tabular}

\section{TOWS Matrix}

Based on previous analysis which derived from SWOT analysis, BPJS Ketenagakerjaan must have a strategy that aims to increase the number of participants through improving service quality. The following table is the TOWS matrix of BPJS Ketenagakerjaan to run its business strategy.

\section{Proposed Organizational Structure}

To support the Institution's growth and its sustainable objectives, BPJS Ketenagekerjaan may need to perform a higher level of diversification based on its function. BPJS Ketenagakerjaan must have organizational structure characteristics that that supports differentiation because it must have the development of innovations that are appropriate to the segment and the connection between each division. Alternative Organizational Structure for BPJS Ketenagakerjaan (Table 8).

\section{Strategy Map}

In this research, the author also suggests a strategic map as a guide to an implementation plan to support the differentiation strategy derived from the main criteria in business level. The figure below shows the strategic maps of BPJS Ketenagakerjaan. 
Table 7.

TOWS Matrix of BPJS Ketenagakerjaan

\begin{tabular}{|c|c|c|}
\hline TOWS & & Strategy \\
\hline \multirow{3}{*}{$\begin{array}{l}\text { SO } \\
\text { Strategies }\end{array}$} & 1 & Collaboration/Empowering strategic partners.(S1 S2 O2 O3) \\
\hline & 2 & $\begin{array}{l}\text { Develop derivative products to provide added value to participants. } \\
\text { (S2 S4 O1 O8) }\end{array}$ \\
\hline & 3 & Improve data quality (S1 S7 O8) \\
\hline \multirow[t]{3}{*}{$\begin{array}{l}\text { WO } \\
\text { Strategies }\end{array}$} & 2 & $\begin{array}{l}\text { Develop or re-organize existing Organizational Structure align with } \\
\text { organizational strategy (W5 W8 O2 O4) } \\
\text { Enhance infrastructure and capacity IT to provide reliability in } \\
\text { business process and service quality (W3 O3 O8) }\end{array}$ \\
\hline & 3 & Improve the manpower planning system (W6 W8 07) \\
\hline & 4 & Digitalization and automation of work processes (W4 O3 O5) \\
\hline \multirow{3}{*}{$\begin{array}{c}\text { ST } \\
\text { Strategies }\end{array}$} & 1 & Improve the standardization of marketing agency system (S3 T5 T6) \\
\hline & 2 & IT development to develop business processes and services (S7 T4 T5) \\
\hline & 3 & $\begin{array}{l}\text { Designing training programs and competency development } \\
\text { according to organizational needs (S2 S8 T3 T5 T8) }\end{array}$ \\
\hline \multirow{5}{*}{$\begin{array}{l}\text { WT } \\
\text { Strategies }\end{array}$} & 1 & $\begin{array}{l}\text { Expand the scope and type of marketing communications based on } \\
\text { membership segment (W2 W5 T1 T3 T8) }\end{array}$ \\
\hline & 2 & Implementation of service units in all districts/cities (W1 W7 T5 T7) \\
\hline & 3 & Strengthening KPI to focus more on service quality (W5 W7 T5) \\
\hline & 4 & $\begin{array}{l}\text { Conduct outsourcing model analysis for the non-core business } \\
\text { activity (W1 W6 T5 T7) }\end{array}$ \\
\hline & 5 & $\begin{array}{l}\text { Develop customer relationship and community relationship (W2 W5 } \\
\text { T3 T8) }\end{array}$ \\
\hline
\end{tabular}

Table 8.

Description Modification in BPJSTK's Organizational Structure

\begin{tabular}{ll}
\hline \multicolumn{1}{c}{ Directorate } & \multicolumn{1}{c}{ Recommendation } \\
\hline $\begin{array}{l}\text { Directorate of Strategic } \\
\text { planning and } \\
\text { development }\end{array}$ & $\begin{array}{l}\text { - Improve the existing business functions and adding new functions by } \\
\text { adding business development and marketing functions } \\
\text { - Improve position and responsibility to be able to integrate all division } \\
\text { functions and monitoring the implementation of strategies. }\end{array}$ \\
$\begin{array}{l}\text { Directorate of } \\
\text { Operations }\end{array}$ & $\begin{array}{l}\text { - New Director Position } \\
\text { - Improve the existing business functions and adding new functions } \\
\text { Directorate of } \\
\text { Compliance }\end{array}$ \\
$\begin{array}{l}\text { Directorate of Human Director Position to strengthening institutions of public legal } \\
\text { Resources and GA }\end{array}$ & $\begin{array}{l}\text { - Improve the current business functions } \\
\text { Directorate of }\end{array}$ \\
$\begin{array}{l}\text { Investment } \\
\text { Directorate of Finance }\end{array}$ & - Re-organizing business function \\
\hline
\end{tabular}




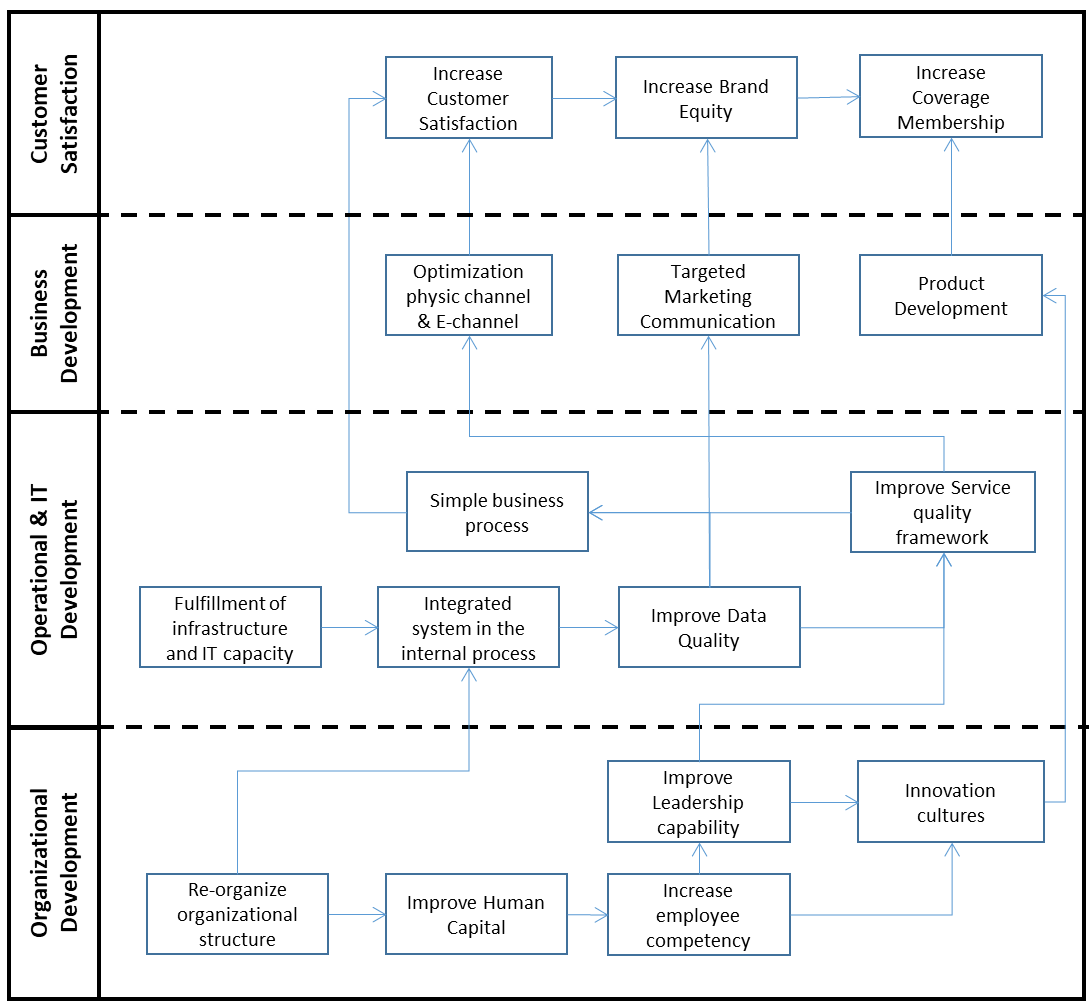

Figure 3.

Strategy Map of BPJS Ketenagakerjaan

\section{CONCLUSIONS}

After analyzing the conditions and current situation faced by BPJS Ketenagakerjaan, there are some conclusions to convey:

- BPJS Ketenagakerjaan has the resources to build capabilities and core competencies to realize competitive advantages. In other words, BPJS Ketenagakerjaan has the potency to acquire the required competencies in order to grasp the market potential by increasing the number of participants

- Based on service quality for customer gap, BPJS Ketenagakerjaanstill has a gap with service quality and must improve the dimensions of reliability and responsiveness to increase participants' satisfaction. It is because these two dimensions are dimensions that have the most substantial gap in participants' perceptions.

- Based on service quality for provider gaps, BPJS Ketenagakerjaanstill has a gap with service quality and must create a simple business process, integrated IT system, and effective marketing communication.

- Four main criteria considered can support the BPJS Ketenagakerjaan strategy, including IT Development, Business Development, Organizational Development, and Customer Satisfaction. These criteria are related to the organizational and functional capabilities needed to execute strategy. 
- BPJS Ketenagakerjaan needs to develop an organizational structure that aligns with the alternative strategy to build core competencies that can increase participant satisfaction.

- By improving the service quality, particularly on reliability and responsiveness, rectifying the business process using the integrated IT system, and enhancing the effective marketing communication levered by the cooperative form organizational structure, BPJS will be able to increase the number of participants.

\section{REFERENCES}

Asosiasi Penyelenggara Jasa Internet Indonesia (APJII). 2017. Laporan Tahunan.

BPJS Ketenagakerjaan. 2017. Laporan Tahunan.

Government of Indonesia. 2004. Law number 40 concerning the National Social Security System.

Government of Indonesia. 2011. Law number 24 concerning Social Security Administrator.

Kientzler, F. 2011. E-government/e-administration: The quest for efficiency and a new relationship with clients. Chapter 6.

Otoritas Jasa Keuangan (OJK). 2017. Laporan Tahunan.

Parasuraman, A., and Grewal, D. 2000. Serving Customers and Consumers Effectively in the Twenty-First Century: A Conceptual Framework and Overview, Journal of the Academy of Marketing Science. Winter. 28(1): 9-16.

Taherdoost, H. 2017. Sampling Methods in Research Methodology; How to Choose a Sampling Technique for Research. International Journal of Academic Research in Management (IJARM). 5(2).

World Bank. 2018. Annual Report. 